\title{
Occurrence of Amphiorchis indicus Mehrotra, 1973 (Digenea, Spirorchiidae) infecting Green turtle Chelonia mydas Linnaeus, 1758 (Testudines, Cheloniidae) in Brazil
}

\author{
Werneck, MR. ${ }^{a *}$ and Silva, RJ. ${ }^{b}$ \\ ${ }^{a}$ BW Consultoria Veterinária, Rua Ponciano Eugênio Duarte, 203, Centro, CEP 11680-000, Ubatuba, SP, Brazil

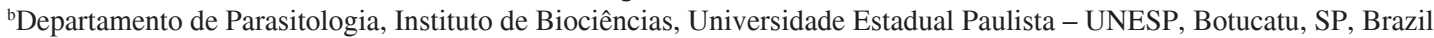 \\ *e-mail: max@bwvet.com.br
}

Received March 19, 2012 - Accepted May 11, 2012 - Distributed February 28, 2013

(With 1 figure)

The family Spirorchiidae was created by Stunkard (1921) and includes approximately 100 species distributed among 19 genera described parasitising terrestrial and aquatic chelonians (Platt, 2002). Ten of these genera are exclusive to sea turtles (Smith, 1997).

The genus Amphiorchis Price 1934 was created to house the species Amphiorchis amphiorchis Price, 1934, found in a specimen of Chelonia mydas Linnaeus, 1758. There are currently five other species accepted for this genus: A. lateralis Oguro, 1938, A. indicus Mehrotra, 1973, A. caborojoensis Fischthal \& Acholonu 1976, A. indicum Simha \& Chattopadhyaya, 1980 (Smith, 1997) and A. solus n. comb. (Simha and Chattopadhyaya, 1970) (Platt, 2002). The present study reports the occurrence of $A$. indicus in C. mydas for the first time in Brazilian waters.

The hosts had their circulatory system examined according to the method described by Snyder and Clopton (2005) and simplified by Werneck et al. (2006). The helminths $(n=5)$ were fixed in AFA (Alcohol-FormalinAcetic Acid) solution under cover slip pressure, stained with chloridric carmine and analysed on a computerised system for image analysis (QWin Lite 3.1 - Leica). Morphometrical values (in micrometres) are shown as mean and range (minimum-maximum). The helminths collected during the study were deposited in the Coleção Helmintológica do Instituto de Biociências (CHIBB) of the Universidade Estadual Paulista, Botucatu, in the state of São Paulo, Brazil (Numbers 4046, 4048, 4991-4995). All collections were authorised by federal licenses for activities for scientific purposes (SISBIO 12421-1 and 12431-2).

Prevalence, mean infection intensity and mean abundance values were determined by species based on Bush et al. (1997).

\section{Results}

A total of 348 specimens of $C$. mydas underwent necropsy between 2008 and 2010 and specimens of $A$. indicus were found in six individuals, with a prevalence rate of $1.7 \%$ and mean intensity of $2.3 \pm 0.8$ ( 1 to 6 ). The specimens were found in the gastrointestinal tract $(n=8)$ of two hosts and the liver $(\mathrm{n}=6)$ of four hosts. Hosts positive for $A$. indicus were from the southern coast of Rio de Janeiro state $(\mathrm{n}=2)$ and the northern coast of São Paulo state $(n=4)$, Brazil. Table 1 displays the results of the morphometric analysis $(n=5)$.

\section{Amphiorchis indicus Mehrotra, 1973 (Figure 1, Table 1)}

\subsection{Description}

Body small, with thin extremities, wider in the testicular region, surface without spines; Oral sucker small and terminal;

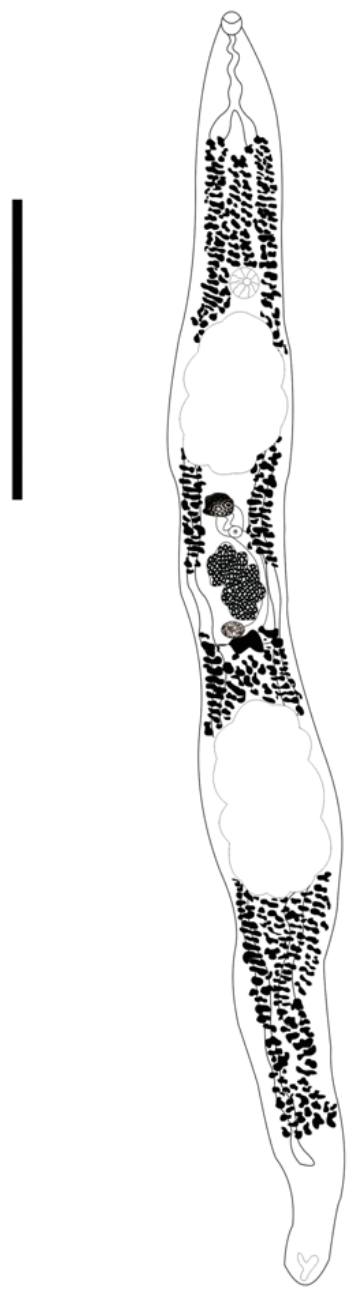

Figure 1. Amphiorchis indicus Mehrotra, 1973 (Digenea: Spirorchiidae) from green turtle Chelonia mydas Linnaeus, 1758 (Testudines: Chelonidae), from Brazil. Scale bar $1 \mathrm{~mm}$. 
Table 1. Morphometric data, in millimetres, of Amphiorchis indicus Mehrotra, 1973 (Digenea: Spirorchiidae) from marine turtles (Testudines: Chelonidae).

\begin{tabular}{|c|c|c|}
\hline & Gupta and Mehrotra (1981) & Present report \\
\hline Host & Eretmochelys imbricata & Chelonia mydas \\
\hline Locality & Gulf of Mannar (India) & São Paulo and Rio de Janeiro States (Brazil) \\
\hline Site of infection & Liver & $\begin{array}{c}\text { Oesophagus, stomach, small intestine, } \\
\text { large intestine and liver }\end{array}$ \\
\hline Number of parasites & 22 & 5 \\
\hline Body length & $2.69-3.517$ & $4.48 \pm 0.62(3.59-5.04)$ \\
\hline Body width & $0.246-0.396$ & $0.327 \pm 0.04(0.29-0.39)$ \\
\hline Oral sucker length & $0.059-0.077$ & $0.095 \pm 0.021(0.070-0.122)$ \\
\hline Oral sucker width & $0.045-0.069$ & $0.066 \pm 0.012(0.054-0.083)$ \\
\hline Acetabulum length & $0.041-0.082$ & $0.116 \pm 0.04(0.077-0.167)$ \\
\hline Acetabulum width & $0.077-0.110$ & $0.098 \pm 0.039(0.055-0.148)$ \\
\hline Esophagus length & $0.295-0.426$ & $0.438 \pm 0.102(0.312-0.550)$ \\
\hline $\begin{array}{l}\text { From the end of right caecum until } \\
\text { the final extremity of the body }\end{array}$ & $0.196-0.278$ & $0.584 \pm 0.108(0.448-0.713)$ \\
\hline $\begin{array}{l}\text { From the end of left caecum until } \\
\text { the final extremity of the body }\end{array}$ & $0.418-0.639$ & $0.948 \pm 0.222(0.615-1.077)$ \\
\hline Anterior testis length & $0.139-0.278$ & $0.568 \pm 0.160(0.329-0.679)$ \\
\hline Anterior testis width & $0.155-0.221$ & $0.261 \pm 0.049(0.197-0.317)$ \\
\hline Posterior testis length & $0.393-0.557$ & $0.597 \pm 0.094(0.493-0.691)$ \\
\hline Posterior testis width & $0.196-0.278$ & $0.266 \pm 0.025(0.236-0.287)$ \\
\hline Ovary length & $0.172-0.311$ & $0.284 \pm 0.040(0.231-0.324)$ \\
\hline Ovary width & $0.155-0.196$ & $0.212 \pm 0.030(0.185-0.239)$ \\
\hline Mehlis`gland length & $0.069-0.118$ & $0.121 \pm 0.015(0.099-0.135)$ \\
\hline Mehlis`gland width & $0.049-0.077$ & $0.076 \pm 0.014(0.063-0.094)$ \\
\hline Cirrus pouch length & $0.069-0.094$ & $0.108 \pm 0.026(0.083-0.137)$ \\
\hline Cirrus pouch width & $0.094-0.135$ & $0.092 \pm 0.012(0.073-0.100)$ \\
\hline External seminal vesicle length & $0.055-0.110$ & $0.138 \pm 0.027(0.103-0.172)$ \\
\hline External seminal vesicle width & $0.073-0.139$ & $0.110 \pm 0.045(0.055-0.163)$ \\
\hline Yolk reservoir length & $0.094-0.172$ & $0.056 \pm 0.019(0.042-0.085)$ \\
\hline Yolk reservoir width & $0.049-0.118$ & $0.120 \pm 0.029(0.097-0.161)$ \\
\hline Egg length & $0.131-0.164$ & $0.167 \pm 0.041(0.138-0.197) \mathrm{n}=3$ \\
\hline Egg width & $0.164-0.205$ & $0.020 \pm 0.0001(0.020-0.020) n=3$ \\
\hline Uterus length & & $0.525 \pm 0.082(0.402-0.579)$ \\
\hline
\end{tabular}

esophagus short and sinuous, approximately one tenth of total body length; Pharynx absent; Ceca small, sinuous, terminating asymmetrically, right cecum longer than left, ceca covered with vitellaria throughout practically their entire length, denser in the region between the end of the esophagus and anterior testicle and between the ovarian region and posterior testicle; Excretory vesicle terminal, Y-shaped; two voluminous testicles in tandem, the anterior of which occupies the area between the acetabulum and outer seminal vesicle and the posterior of which is found after the yolk reservoir, contour irregular, slightly oval, anterior testicle slightly larger than the posterior; External seminal vesicle occupying areas to the left of the cirrus sac and immediately posterior to the anterior testicle, with irregular shape; Cirrus sac with irregular shape, occupying median region between the external seminal vesicle and ovary; Genital pore in median region immediately anterior to the ovary; Uterus short, slightly sinuous, located to the left between the ovary and cecum; Eggs observed; Ovary oval shaped, located between Mehlis' gland and cirrus sac; Mehlis' gland posterior to the intracecal ovary; Vitellaria densely distributed throughout the body, exhibiting small follicles extending from the cecal bifurcation to the extremity of the right cecum; Fields interrupted only in region of the testicle and ovary.

\subsection{Remarks}

Amphiorchis indicus was found in the liver of a sea turtle specimen Eretmochelys imbricata Linnaeus 1758 in 
India (Gupta and Mehrotra, 1981). According to Smith (1997) this species was first identified in a C. mydas, making the validity of the host species discussed. The results of the present study confirm the occurrence of A. indicus in C. mydas.

This study is the second record of this helminth and the first record in sea turtles on the coast of Brazil. The only previous report of $A$. indicus involved the aforementioned specimen of E. imbricata in India, in which 22 specimens of the helminth were found (Gupta \& Mehrotra, 1981). Based on these two isolated descriptions, the prevalence of this parasite can be considered low.

The morphometric analysis of the specimens reveals larger body length and width, larger distance between the end of the right cecum and posterior extremity and larger posterior testicle length in comparison to the data described by Gupta and Mehrotra (1981).

There are few studies on the occurrence of parasites from the family Spirorchiidae in Brazil, with only five species reported thus far: Learedius learedi Price, 1934 (Werneck et al., 2006) and Monticellius indicum Mehra, 1939 (Werneck et al., 2008a) in juvenile specimens of C. mydas; A. solus in an adult specimen of C. mydas (Werneck et al., 2011); and Carettacola stunkardi (Martin \& Bamberger, 1952) Dailey, Fast \& Balazs, 1991 and A. caborojoensis in E. imbricata (Werneck et al., 2008b).

This is the first report of $A$. indicus found in sea turtles from the Brazilian coast, thus providing important information about helminth fauna in this region and broadening the geographical distribution of this species. This report also contributes to the knowledge of morphometrical data of the species.

Acknowledgements - We would like to thank the Fundação de Amparo à Pesquisa do Estado de São Paulo - FAPESP (Proc. 07/59504-7) for the financial support.

\section{References}

BUSH, AO., LAFFERTY, KD., LOTZ, JM. and SHOSTAK, AW., 1997. Parasitology meets ecology on its own terms: Margolis et al. revisited. Jornal of Parasitology, vol. 83, p. 575-583.
GUPTA, NK. and MEHROTRA, V. 1981. On two blood flukes (trematoda) of the family Spirorchiidae Stunkard, 1921 from Indian marine turtles. Acta Parasitologica Polonica, vol. 28, no. 2, p. 11-20.

PLATT, TR., 2002. Family spirorchiidae Stunkard. In GIBSON, DI., JONES, A. and BRAY, RA. (Eds.). Keys to the Trematoda. London: CABI Publishing. p. 453-467.

SMITH, JW., 1997. The blood flukes (Digenea: Sanguinicolidae and Spirorchiidae) of cold-blooded vertebrates: part. 2. Helminthological Abstracts, vol. 6, no. 10, p. 329-344.

SIMHA, SS. and CHATTOPADHYAYA, DR. 1970. A new genus and species of a blood flukes, Squaroacetabulum solus, from the ventricle of the heart of a marine turtle, Chelone mydas. Zoologischer Anzeiger, vol. 184, p. 290-294.

SNYDER, S. and CLOPTON, R., 2005. New methods for the collection and preservation of spirorchiid trematodes and Polystomatid manogeneus from turtles. Comparative Parasitology, vol. 72, no. 1, p. 102-107. http://dx.doi.org/10.1654/4155

WERNECK, MR., BECKER, JH., GALLO, BMG. and SILVA, RJ., 2006 Learedius learedi Price 1934 (Digenea, Spirorchiidae) in Chelonia mydas Linnaeus 1758 (Testudines, Chelonidae) in Brazil: case report. Arquivo Brasileiro de Medicina Veterinária e Zootecnia, vol. 58 no. 4, p. 550-555. http://dx.doi.org/10.1590/ S0102-09352006000400016

WERNECK, MR., GALLO BMG. and SILVA RJ., 2008a. First report of Monticellius indicum Mehra, 1939 (Digenea: Spirorchiidae) infecting Chelonia mydas Linnaeus, 1758 (Testudines: Chelonidae) from Brazil. Brazilian Journal of Biology, vol. 68, no. 2, p. 455-456. PMid:18660980. http://dx.doi.org/10.1590/ S1519-69842008000200033

-, 2008b. Spirorchiids (Digenea: Spirorchiidae) infecting a Hawksbill sea turtle Eretmochelys imbricata (Linnaeus 1758) from Brazil. Arquivo Brasileiro de Medicina Veterinária e Zootecnia, vol. 60, no. 3, p. 663-666. http://dx.doi.org/10.1590/ S0102-09352008000300021

WERNECK, MR., GALLO, B., LIMA, EHDM. and SILVA, RJ., 2011. Occurrence of Amphiorchis solus Simha \& Chattopadhyaya, 1970 (Digenea, Spirorchiidae) infecting Green turtle Chelonia mydas Linnaeus, 1758 (Testudines, Cheloniidae) in Brazil. Comparative Parasitology, vol. 78, no. 1, p. 200-203. 
